\title{
Importance of Toll-Like Receptor 9 in Host Defense against M1T1 Group A Streptococcus Infections
}

\author{
Annelies S. Zinkernagel ${ }^{a, e}$ Petr Hruz ${ }^{c}$ Satoshi Uchiyama ${ }^{a, e}$ \\ Maren von Köckritz-Blickwede ${ }^{a, g}$ Reto A. Schuepbach ${ }^{d, f}$ Tomoko Hayashic $^{c}$ \\ Dennis A. Carson ${ }^{c}$ Victor Nizet ${ }^{a, b}$

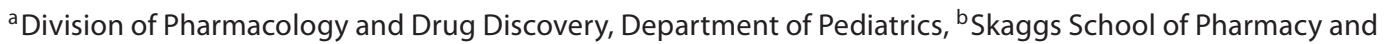 \\ Pharmaceutical Sciences, and ${ }^{C}$ Department of Medicine, University of California, San Diego, Calif., and \\ ${ }^{\mathrm{d} S c r i p p s}$ Research Institute, La Jolla, Calif., USA; Divisions of e Infectious Diseases and ${ }^{\mathrm{f} I n t e n s i v e ~ C a r e, ~}$ \\ University Hospital Zurich, University of Zurich, Zurich, Switzerland; ${ }^{9}$ Department of Physiological Chemistry, \\ University of Veterinary Medicine, Hannover, Germany
}

\section{Key Words}

Toll-like receptor 9 - Group A Streptococcus · Innate immunity

\begin{abstract}
Timely recognition and elimination of invasive group $A$ Streptococcus (GAS) by innate immunity is crucial to control infection. The intracellular pattern recognition receptor Tolllike receptor 9 (TLR9) promotes macrophage hypoxia-inducible factor- $1 \alpha$ levels, oxidative burst and nitric oxide production in response to GAS. TLR9 contributes to GAS clearance in vivo in both localized cutaneous and systemic infection models.

Copyright $\odot 2012$ S. Karger AG, Basel
\end{abstract}

\section{Introduction}

The Gram-positive bacterium group A Streptococcus (GAS) is a leading human pathogen causing $>700$ million superficial infections such as pharyngitis or pyoderma and $>650,000$ invasive infections worldwide every year
[1]. The host's initial defense mechanisms against GAS involve the physical barriers of mucosa or skin and their commensal microflora. Once GAS has breached the epithelium, eradication by soluble factors and phagocytes is required, and quick and accurate recognition of GAS by the host innate immune system can prevent disease spread. Pattern recognition receptors such as Toll-like receptors (TLRs) recognize conserved molecular patterns from pathogens; most TLRs will initiate signal transduction via the central adaptor protein myeloid differentiation factor 88 (MyD88). MyD88 has recently been shown to play an important role in innate defense against GAS infection [2].

Though classically described as an extracellular pathogen, studies have shown that GAS may survive intracellularly for several hours within epithelial cells [3-5], macrophages $[6,7]$ and neutrophils $[8,9]$. These data led us to hypothesize that the intracellularly localized TLR9 could be important for GAS detection and elimination. TLR9 is found in endosomes and is stimulated by nonmethylated DNA and synthetic CpG oligodeoxynucleotides [10, 11] or during infection with obligate intracellular bacteria including Listeria monocytogenes and Legionella pneu-

\section{KARGER \\ Fax +41613061234 E-Mail karger@karger.ch} www.karger.com
() 2012 S. Karger AG, Basel

$1662-811 X / 12 / 0042-0213 \$ 38.00 / 0$

Accessible online at:

www.karger.com/jin
Dr. Annelies S. Zinkernagel

Division of Infectious Diseases and Hospital Epidemiology

University Hospital Zurich, University of Zurich

Rämistrasse 100, CH-8091 Zurich (Switzerland)

Tel. +41 44255 4395, E-Mail annelies.zinkernagel@usz.ch 
mophila $[12,13]$. To date, the role of TLR9 in innate defense against bacteria that exist mainly extracellulary has not been fully elucidated $[14,15]$ and remains controversial [16-19].

\section{Methods}

\section{Mice and Bacterial Strains}

C57BL/6 wild-type (WT) and TLR9-deficient mice in the C57BL/6 background were used in this study. TLR9-deficient mice were a gift from Dr. Shizuo Akira (Osaka University, Japan) and were bred and handled in our facilities under the approved protocols of the University of California San Diego Animal Care Committee. WT mice were purchased from Charles River.

GAS M1T1 strain 5448 was originally isolated from a patient with necrotizing fasciitis and toxic shock syndrome [20]. GAS were propagated in Todd-Hewitt broth (Difco, BD Diagnostics) or Todd-Hewitt agar plates. In macrophage and mouse challenge studies, bacteria were grown to logarithmic phase in ToddHewitt broth [optical density at $600 \mathrm{~nm}=0.4=$ approx. $2 \times 10^{8}$ colony-forming units $(\mathrm{CFU}) / \mathrm{ml}]$, pelleted, washed and resuspended in PBS or in tissue culture media at the desired concentration.

\section{Macrophage Killing Assays}

Peritoneal macrophages were isolated from the peritoneal cavity of WT and TLR9-deficient mice $72 \mathrm{~h}$ after injection of thioglycollate, as previously described [21]. Harvested macrophages were washed and resuspended in RPMI-1640 containing 10\% heat-inactivated fetal bovine serum (FBS). In a 48 -well plate, $10^{6}$ macrophages were added per well and incubated for $24 \mathrm{~h}$ at $37^{\circ} \mathrm{C}$ with $5 \% \mathrm{CO}_{2}$. Then cells were washed twice and resuspended in RPMI1640 containing 2\% FBS. Where indicated, the TLR9 antagonist guanosine-rich inhibitory oligonucleotide (G-ODN; $5 \mu \mathrm{M}$; Invivogen, Carlsbad, Calif., USA) was added. After $1 \mathrm{~h}$, logarithmic phase bacteria were added to the wells at a final multiplicity of infection (MOI) of 0.1-0.2 and centrifuged for $5 \mathrm{~min}$ at $1,500 \mathrm{rpm}$. After $4 \mathrm{~h}$ of incubation at $37^{\circ} \mathrm{C}$ with $5 \% \mathrm{CO}_{2}$, macrophages were detached with trypsin and lysed with $0.025 \%$ Triton X in PBS for serial dilutions to enumerate surviving bacteria (plated on ToddHewitt agar).

\section{Oxidative Burst and Nitric Oxide Expression}

For reactive oxygen species (ROS) determination, bone marrow (BM)-derived macrophages were used. The BM cells of femurs and tibias of WT and TLR9-deficient mice were collected. Cells were plated in Dulbecco's modified Eagle medium supplemented with $10 \%$ heat-inactivated FBS and 30\% conditioned medium as described elsewhere [22]. Mature adherent BM-derived macrophages were harvested by gentle scraping after 7 days in culture and reseeded for the assay. On day 10, macrophages were washed twice, resuspended in Hanks' balanced salt solution and incubated with $30 \mu \mathrm{M} 2^{\prime}, 7^{\prime}$-dichlorofluorescein diacetate for $30 \mathrm{~min}$ of rotation at $37^{\circ} \mathrm{C}$. Cells were washed 3 times with PBS and resuspended in Hanks' balanced salt solution for a final concentration of $5 \times 10^{5}$ in $100 \mu$ l of solution per well of a 96-well plate. Where indicated, logarithmic phase bacteria were added at an MOI of 1:1. After $270 \mathrm{~min}$, the fluorescence signal was measured with excitation at $485 \mathrm{~nm}$ and emission at $535 \mathrm{~nm}$ using a fluorescent plate reader (Wallac II, Perkin Elmer). Nitric oxide (NO) expression was determined by the Griess reaction in peritoneal macrophages as previously described [23]; baseline values (no GAS stimulation) were subtracted from indicated values.

\section{Hypoxia-Inducible Factor-1 $\alpha$ Detection by Western Blot and} Immunostaining

BM-derived macrophages were harvested and cultured as described above. After 7 days in culture, mature macrophages were reseeded into $100-\mathrm{mm}^{2}$ wells for Western blot analysis or onto 12$\mathrm{mm}^{2}$ glass cover slides in 24-well plates for immunostaining. Macrophages were then either challenged with WT GAS (MOI 10) or were not exposed to bacteria. After $1 \mathrm{~h}$ of incubation, penicillin and gentamicin (10 and $100 \mu \mathrm{g} / \mathrm{ml}$, respectively) were added to all the wells and macrophages were incubated for an additional $3 \mathrm{~h}$. For Western blot analysis, cells were harvested and washed (in PBS), and proteins were extracted with RIPA buffer. Nuclear extracts $(20 \mu \mathrm{g})$ were loaded onto a $12 \%$ Tris-tricine gel in a $2-(\mathrm{N}$ morpholino)ethanesulfonic acid buffer (Invitrogen) for hypoxiainducible factor (HIF)-1 $\alpha$ Western blot using standard methodologies [24]. For immunostaining, cells were immediately fixed with $4 \%$ paraformaldehyde and kept at $4^{\circ} \mathrm{C}$ until further analysis. After washing, cells were permeabilized for 45 min with PBS containing $2 \% \mathrm{BSA}, 0.2 \%$ Triton $\mathrm{X}-100$ and $5 \%$ goat serum.

After additional washes, rabbit anti-HIF-1 $\alpha$ (Novus Biologicals; diluted 1:100 in PBS-Tween) was added for $60 \mathrm{~min}$ at room temperature followed by Alexa Fluor 488-conjugated goat antirabbit IgG (green; Invitrogen; diluted 1:500 in PBS-Tween) for $45 \mathrm{~min}$ at room temperature. After washing, samples were embedded in Prolong Gold antifade containing DAPI for counterstaining (blue; Invitrogen). Mounted samples were examined using an inverted confocal laser scanning 2-photon microscope (Olympus Fluoview FV1000, Olympus × 20/0.7 UPlanSApo objective) with Fluoview ${ }^{\mathrm{TM}}$ Spectral Scanning technology (Olympus America, Center Valley, Pa., USA) or, alternatively, using a Zeiss Axiolab microscope (Zeiss $\times 20 / 0.5$ Plan-Neofluor objective; Carl Zeiss, San Diego, Calif., USA) with an attached Sony Digital Photo Camera DKC-5000 (Sony, USA) at calibrated magnifications. Mean fluorescence intensities as markers for HIF-1 $\alpha$ expression levels were measured at equal exposure times and quantified using Image J (National Institutes of Health, Bethesda, Md., USA). HIF-1 $\alpha$ levels were calculated by dividing the HIF-1 $\alpha$-specific signal by the background subtracted DAPI-related signal.

\section{Mouse Infection Models}

Logarithmic phase GAS were resuspended in PBS and mixed 1:1 with sterile Cytodex beads (Sigma, St. Louis, Mo., USA), and an inoculum of $5 \times 10^{7} \mathrm{CFU}$ of GAS was injected subcutaneously into one flank of 10- to 12-week-old WT or TLR9-deficient mice (total injected volume per mouse $100 \mu \mathrm{l}$ ). The size of developing necrotic lesions was monitored daily for 4 days, at which time mice were euthanized and skin lesions were harvested for bacterial counts. In systemic challenge experiments, 12-week-old mice (WT and TLR9-deficient) were given intraperitoneal injections of mid-log phase GAS $\left(5 \times 10^{7} \mathrm{CFU}\right)$ in $500 \mu \mathrm{l}$ of PBS or PBS alone as a control. After $24 \mathrm{~h}$, blood was collected for bacterial counts. 


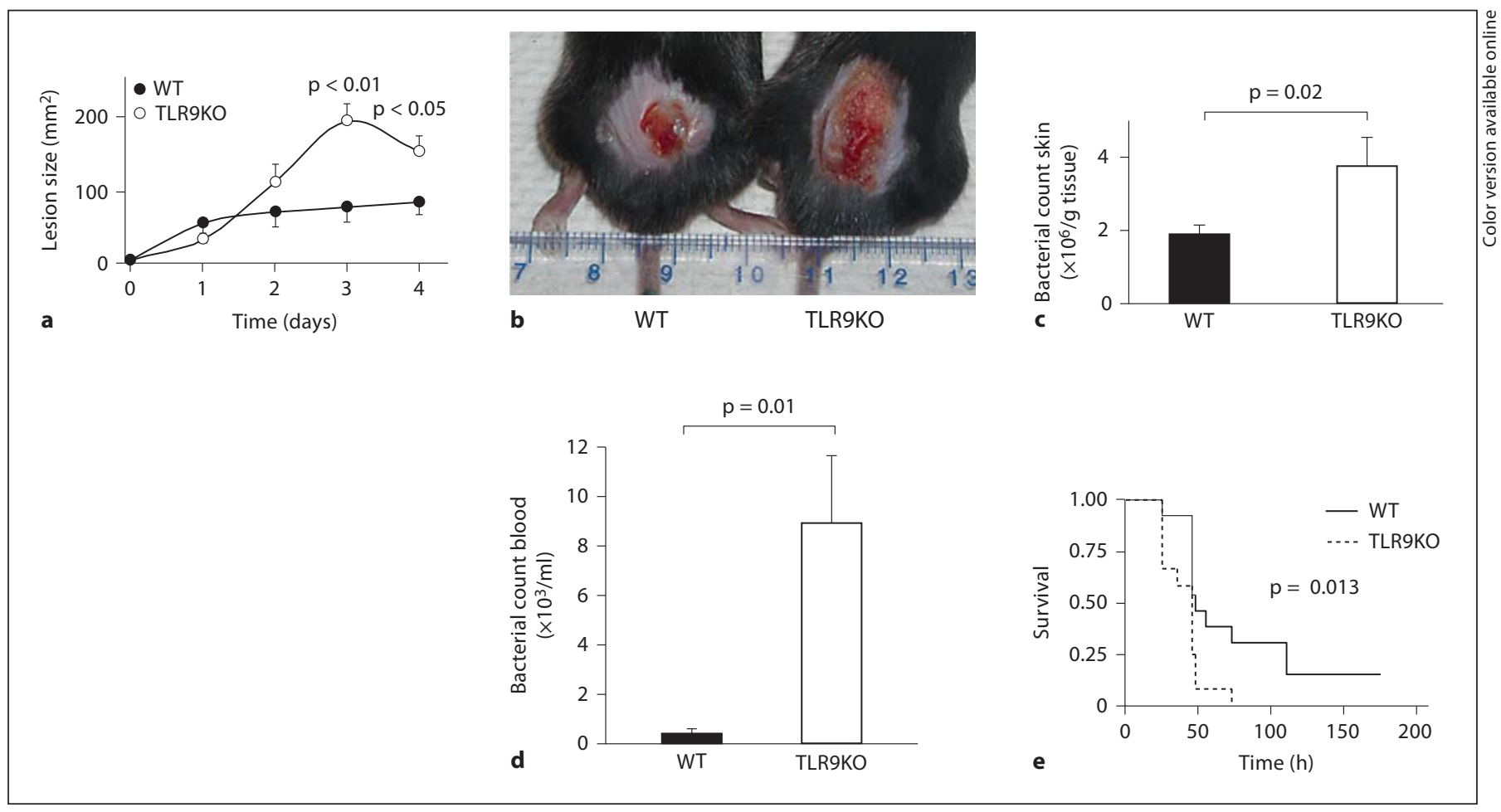

Fig. 1. TLR9 is important for controlling GAS infection in vivo. a C57BL/6 (WT) and TLR9-deficient mice were injected subcutaneously with equivalent inocula of the M1 GAS strain, and skin lesion progression was measured for 4 days. b Representative photograph of skin lesions seen in the subcutaneous challenge experiment. c After 4 days, there were twice as many bacteria in the skin in the TLR9-deficient mice compared to the WT mice. d Using an intraperitoneal infection model, a subset of the mice (5 WT and 4 TLR9-deficient mice) were bled $24 \mathrm{~h}$ after GAS infection, and bacteremia was evaluated by serial dilution of the blood. e Survival of WT $(n=13)$ and TLR9-deficient $(n=12)$ mice followed over 1 week after intraperitoneal infection. Data are presented as means \pm SEM. TLR9KO = TLR9-deficient.

\section{Statistics}

For comparisons of two groups of either paired or unpaired samples we used the nonparametric Wilcoxon test or t test, and for 3-sample comparison we used nonparametric Kruskal-Wallis one-way ANOVA on ranks. If the ANOVA analysis was significant, Bonferroni pair-wise group comparison was performed. The log rank test was used for survival analysis. p values were calculated using the software packages NCSS 2007 (NCSS, Kaysville, Utah, USA) and SPSS Statistics 17.0 (SPSS, Chicago, Ill., USA).

\section{Results and Discussion}

To directly test the importance of TLR9 for the recognition and clearance of GAS in vivo, we challenged WT and TLR9-deficient mice with the invasive M1T1 GAS strain 5448 using a previously described model of necrotizing subcutaneous infection [25] and monitored the development of lesions over 4 days. TLR9-deficient mice de- veloped significantly larger necrotizing skin lesions than did WT mice (fig. 1a, b). Mice were sacrificed on day 4, and the bacterial load in the excised skin lesions of TLR9deficient mice was significantly higher than that in WT controls (fig. 1c).

GAS can cause bacteremic infections and toxic shock syndrome with high morbidity and mortality. To test the importance of TLR9 in a systemic infection model, WT and TLR9-deficient mice were injected intraperitoneally with logarithmic phase M1T1 GAS, and blood was collected at $24 \mathrm{~h}$ for enumeration of CFUs. TLR9-deficient mice resolved GAS bacteremia less effectively than did WT mice (fig. 1d), and the impaired GAS clearance observed in TLR9-deficient mice was reflected in increased mortality (fig. 1e). Altogether, these animal data show for the first time that TLR9 is important for controlling GAS in vivo during localized cutaneous or systemic infection. 


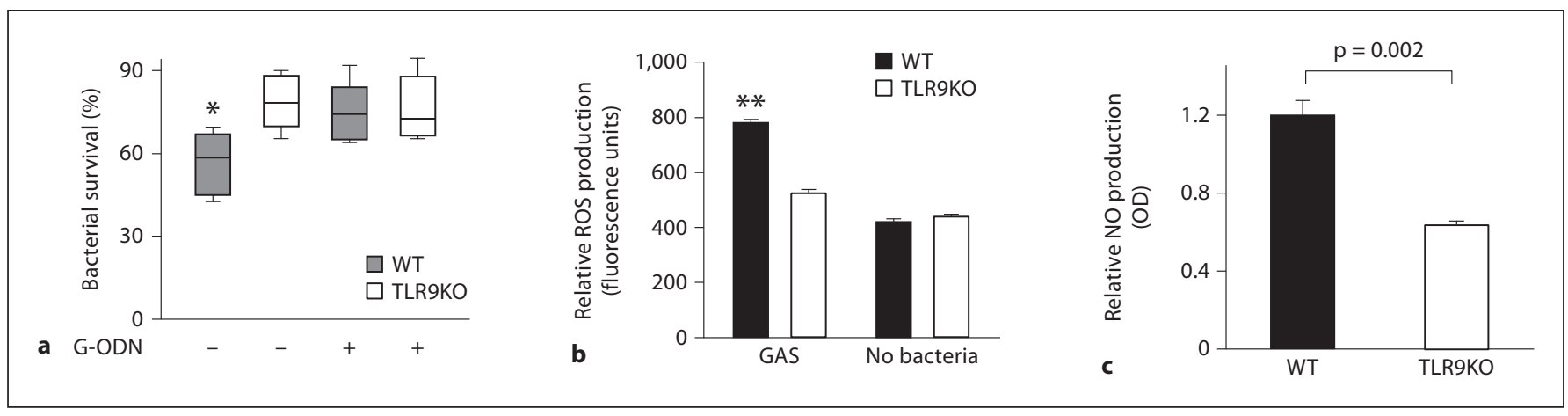

Fig. 2. TLR9 mediates killing of GAS by macrophages. a Surviving GAS after incubation with WT macrophages or TLR9-deficient macrophages at an MOI of 1, with and without the TLR9 antagonist G-ODN. b, c WT and TLR9-deficient macrophages were incubated with GAS at an MOI of 1 , and ROS (b) and NO (c) was quantified. Data are given as box plots with $n=6$ per point and 3 repeats (a) or as means \pm SEM with $n=6(\mathbf{b})$ and $n=3(\mathbf{c})$ (representative experiment from 3 independent experiments). ANOVA was significant at $\mathrm{p}=0.01$, with Bonferroni pair-wise group comparison at ${ }^{*} \mathrm{p}<0.05$ and ${ }^{*} \mathrm{p}<0.005$. TLR9KO $=$ TLR9-deficient; OD = optical density at $540 \mathrm{~nm}$.
Fig. 3. TLR 9 promotes HIF- $1 \alpha$ expression. WT and TLR9-deficient macrophages were challenged with GAS. a Representative immunofluorescence micrograph. b Quantification of HIF-1 $\alpha$ expression (infected cells, $\mathrm{n}=14$, images of 3 independent experiments; noninfected cells, $\mathrm{n}=8$, images of 2 independent experiments). c Nuclear extracts of the same cells were analyzed for HIF-1 $\alpha$ expression by Western blot with analysis of $\beta$-actin as a loading control. Data are presented as means \pm SEM. Scale bars $=100 \mu \mathrm{m}$. TLR9KO = TLR9-deficient; n.s. = not significant.

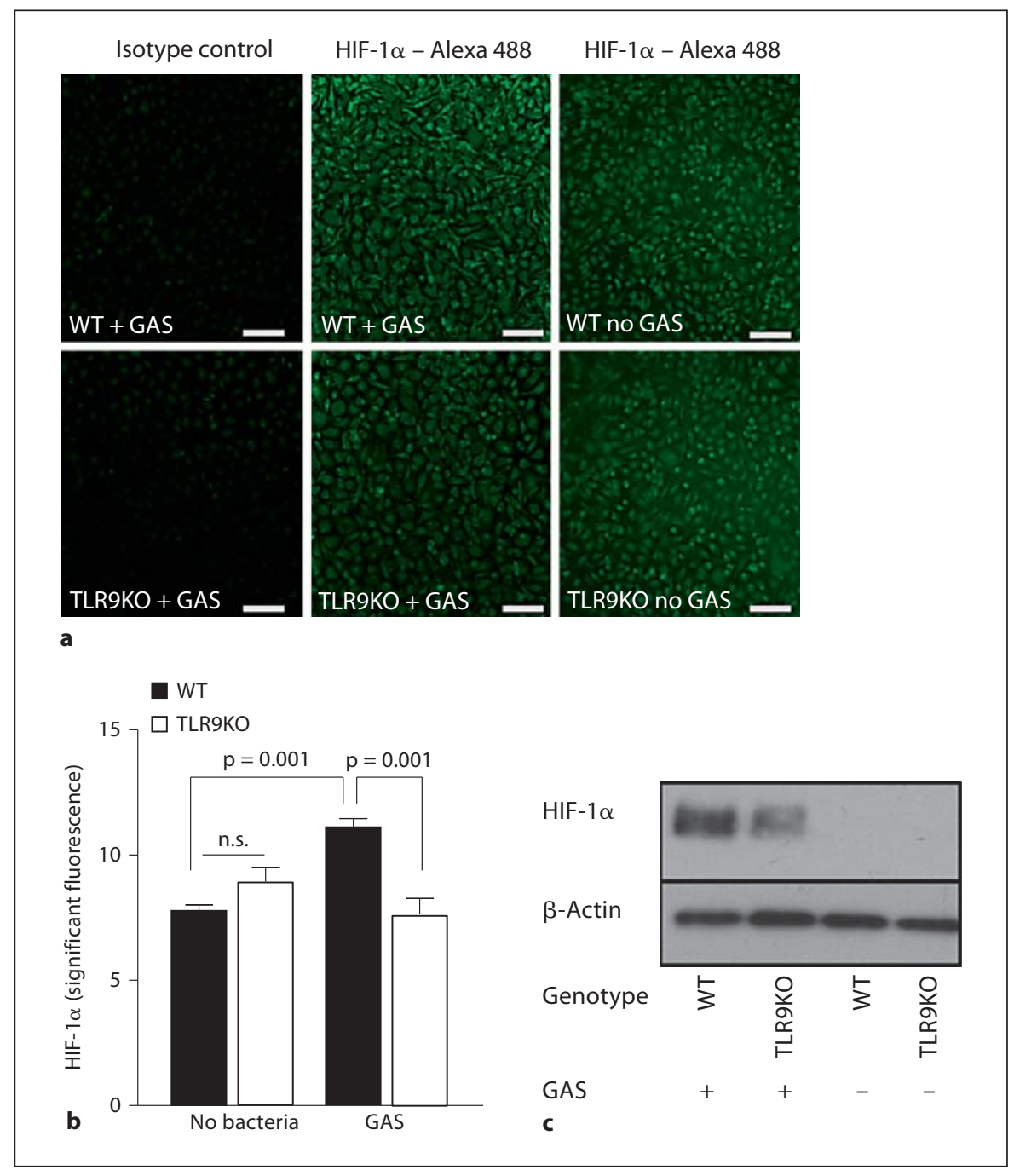


Macrophages, which express TLR9 [26], play a key role in the defense against GAS infections $[27,28]$. We hypothesized that the impaired clearance of GAS in TLR9deficient animals could be explained by inefficient killing of GAS by macrophages lacking TLR9 signaling. We thus studied the contribution of TLR9 to GAS clearance using in vitro killing assays and genetically or pharmacologically modified murine macrophages. GAS was killed efficiently when incubated with WT macrophages; however, killing was significantly impaired if TLR9 was absent or pharmacologically blocked by the TLR9 antagonist G-ODN (fig. 2a).

Macrophages kill GAS efficiently in part through production of ROS and NO [28]. Macrophages from WT and TLR9-deficient mice were incubated with GAS, and ROS and NO production was quantitated after $30 \mathrm{~min}$. TLR9deficient macrophages produced significantly less ROS (fig. 2b) and NO (fig. 2c) in response to GAS than did WT macrophages. These results suggest that impaired control of GAS infection in TLR9-deficient mice may in part be related to diminished NO- and ROS-mediated macrophage killing.

HIF- $1 \alpha$ is a key transcriptional regulator orchestrating myeloid cell inflammatory and innate immune responses [29]. GAS infection leads to increased levels of HIF- $1 \alpha$ in macrophages [23], and HIF- $1 \alpha$ is important for regulating macrophage production of ROS and NO in response to infection $[23,30]$. We challenged WT and TLR9-deficient macrophages with GAS and determined the intranuclear content of HIF- $1 \alpha$ by immunostaining (fig. 3a, b; online suppl. fig. 1; for all online suppl. material, see www.karger.com/doi/10.1159/000329550) and Western blotting (fig. 3c). After GAS challenge, HIF-1 $\alpha$ stabilization was less pronounced in TLR9-deficient compared to
WT mouse macrophages. The residual HIF- $1 \alpha$ induction still detectable in the TLR9-deficient mouse macrophages after GAS challenge could be due to the redundant effects of other pattern recognition receptors such as TLR2, TLR4 and TLR6, which contribute to HIF-1 $\alpha$ induction and stabilization [31, 32], likely through NF- $\mathrm{kB}$-dependent increases in HIF-1 $\alpha$ transcript [33]. Also, GAS has been shown to be able to induce multiple inflammatory responses via MyD88-dependent TLR2/TLR4/TLR9-independent signaling [19], as has been shown for other Gram-positive pathogens $[16,34]$.

In summary, this study shows that TLR9 plays an important role in host defense against GAS infections and that stimulation of TLR9 improves macrophage killing of this leading human pathogen. TLR9-induced stabilization of the transcription factor HIF-1 $\alpha$ and increased generation of bactericidal ROS and NO are likely contributing factors to the observed innate immune phenotypes.

\section{Acknowledgement}

We thank Dr. S. Akira (Osaka University, Japan) for providing the initial mouse strains.

\section{Disclosure Statement}

This research was supported by the Swiss National Foundation Grants SSMBS PASMA117303/1 (to A.S.Z.), PASMA-114623 (to P.H.) and PASM33-117302 (to R.A.S.), National Institutes of Health grants AI77780 (to V.N.) and AI077989 (to D.A.C.) and the 'Deutsche Akademie der Naturforscher Leopoldina' (BMBFLPD 9901/8-187, to M.v.K.-B.). The authors declare no conflict of interest.

\section{References}

1 Carapetis JR, Steer AC, Mulholland EK, Weber M: The global burden of group A streptococcal diseases. Lancet Infect Dis 2005;5 685-694

$\checkmark 2$ Loof TG, Goldmann O, Gessner A, Herwald $\mathrm{H}$, Medina E: Aberrant inflammatory response to Streptococcus pyogenes in mice lacking myeloid differentiation factor 88 . Am J Pathol 2010;176:754-763.

- 3 Hakansson A, Bentley CC, Shakhnovic EA, Wessels MR: Cytolysin-dependent evasion of lysosomal killing. Proc Natl Acad Sci USA 2005;102:5192-5197.

\footnotetext{
-4 Osterlund A, Engstrand L: Intracellular penetration and survival of Streptococcus pyogenes in respiratory epithelial cells in vitro. Acta Otolaryngol 1995;115:685-688.

-5 Osterlund A, Engstrand L: An intracellular sanctuary for Streptococcus pyogenes in human tonsillar epithelium - studies of asymptomatic carriers and in vitro cultured biopsies. Acta Otolaryngol 1997;117:883-888.

6 Thulin P, Johansson L, Low DE, Gan BS, Kotb M, McGeer A, Norrby-Teglund A: Viable group A streptococci in macrophages during acute soft tissue infection. PLoS Med 2006;3:e53.
}

\footnotetext{
7 Hertzen E, Johansson L, Wallin R, Schmidt $\mathrm{H}$, Kroll M, Rehn AP, Kotb M, Morgelin M, Norrby-Teglund A: M1 protein-dependent intracellular trafficking promotes persistence and replication of Streptococcus pyogenes in macrophages. J Innate Immun 2010; 2:534-545.

-8 Medina E, Goldmann O, Toppel AW, Chhatwal GS: Survival of Streptococcus pyogenes within host phagocytic cells: a pathogenic mechanism for persistence and systemic invasion. J Infect Dis 2003;187:597-603.
} 
$>9$ Staali L, Morgelin M, Bjorck L, Tapper H: Streptococcus pyogenes expressing $\mathrm{M}$ and $\mathrm{M}$ like surface proteins are phagocytosed but survive inside human neutrophils. Cell Microbiol 2003;5:253-265.

- 10 Hemmi H, Takeuchi O, Kawai T, Kaisho T, Sato S, Sanjo H, Matsumoto M, Hoshino K, Wagner H, Takeda K, Akira S: A toll-like receptor recognizes bacterial DNA. Nature 2000;408:740-745.

-11 Huang LY, Aliberti J, Leifer CA, Segal DM, Sher A, Golenbock DT, Golding B: Heatkilled Brucella abortus induces TNF and IL12 p40 by distinct MyD88-dependent pathways: TNF, unlike IL-12p40 secretion, is Toll-like receptor 2 dependent. J Immunol 2003;171:1441-1446.

-12 Bhan U, Trujillo G, Lyn-Kew K, Newstead MW, Zeng X, Hogaboam CM, Krieg AM, Standiford TJ: Toll-like receptor 9 regulates the lung macrophage phenotype and host immunity in murine pneumonia caused by Legionella pneumophila. Infect Immun 2008;76:2895-2904.

$\checkmark 13$ Leifer CA, Kennedy MN, Mazzoni A, Lee C, Kruhlak MJ, Segal DM: TLR9 is localized in the endoplasmic reticulum prior to stimulation. J Immunol 2004;173:1179-1183.

-14 Albiger B, Dahlberg S, Sandgren A, Wartha F, Beiter K, Katsuragi H, Akira S, Normark S, Henriques-Normark B: Toll-like receptor 9 acts at an early stage in host defence against pneumococcal infection. Cell Microbiol 2007;9:633-644.

15 Sjolinder H, Mogensen TH, Kilian M, Jonsson AB, Paludan SR: Important role for Tolllike receptor 9 in host defense against meningococcal sepsis. Infect Immun 2008;76: 5421-5428.

-16 Henneke P, Takeuchi O, Malley R, Lien E, Ingalls RR, Freeman MW, Mayadas T, Nizet V, Akira S, Kasper DL, Golenbock DT: Cellular activation, phagocytosis, and bactericidal activity against group B streptococcus involve parallel myeloid differentiation factor 88-dependent and independent signaling pathways. J Immunol 2002;169:3970-3977.
17 Wieland CW, Florquin S, van der Poll T: Tolllike receptor 9 is not important for host defense against Haemophilus influenzae. Immunobiology 2010;215:910-914.

-18 Talati AJ, Kim HJ, Kim YI, Yi AK, English BK: Role of bacterial DNA in macrophage activation by group B streptococci. Microbes Infect 2008;10:1106-1113

19 Gratz N, Siller M, Schaljo B, Pirzada ZA, Gattermeier I, Vojtek I, Kirschning CJ, Wagner H, Akira S, Charpentier E, Kovarik P: Group A streptococcus activates type I interferon production and MyD88-dependent signaling without involvement of TLR2, TLR4, and TLR9. J Biol Chem 2008;283: 19879-19887.

$\checkmark 20$ Chatellier S, Ihendyane N, Kansal RG, Khambaty F, Basma H, Norrby-Teglund A, Low DE, McGeer A, Kotb M: Genetic relatedness and superantigen expression in group A streptococcus serotype M1 isolates from patients with severe and nonsevere invasive diseases. Infect Immun 2000;68:3523-3534.

-21 Hruz P, Zinkernagel AS, Jenikova G, Botwin GJ, Hugot JP, Karin M, Nizet V, Eckmann L: NOD2 contributes to cutaneous defense against Staphylococcus aureus through alpha-toxin-dependent innate immune activation. Proc Natl Acad Sci USA 2009;106: 12873-12878.

22 Wu CC, Hayashi T, Takabayashi K, Sabet M, Smee DF, Guiney DD, Cottam HB, Carson DA: Immunotherapeutic activity of a conjugate of a Toll-like receptor 7 ligand. Proc Natl Acad Sci USA 2007;104:3990-3995.

23 Peyssonnaux C, Datta V, Cramer T, Doedens A, Theodorakis EA, Gallo RL, Hurtado-Ziola N, Nizet V, Johnson RS: HIF-1alpha expression regulates the bactericidal capacity of phagocytes. J Clin Invest 2005;115:18061815.

24 Zinkernagel AS, Peyssonnaux C, Johnson RS, Nizet V: Pharmacologic augmentation of hypoxia-inducible factor-1alpha with $\mathrm{mi}$ mosine boosts the bactericidal capacity of phagocytes. J Infect Dis 2008;197:214-217.

25 Zinkernagel AS, Timmer AM, Pence MA, Locke JB, Buchanan JT, Turner CE, Mishalian I, Sriskandan S, Hanski E, Nizet V: The IL-8 protease SpyCEP/ScpC of group A Streptococcus promotes resistance to neutrophil killing. Cell Host Microbe 2008;4:170178.
26 Wagner H: The immunobiology of the TLR9 subfamily. Trends Immunol 2004;25:381386.

27 Goldmann O, Rohde M, Chhatwal GS, Medina E: Role of macrophages in host resistance to group A streptococci. Infect Immun 2004;72:2956-2963.

-28 Goldmann O, von Kockritz-Blickwede M, Holtje C, Chhatwal GS, Geffers R, Medina E: Transcriptome analysis of murine macrophages in response to infection with Streptococcus pyogenes reveals an unusual activation program. Infect Immun 2007;75:41484157.

29 Nizet V, Johnson RS: Interdependence of hypoxic and innate immune responses. Nat Rev Immunol 2009;9:609-617.

$>30$ Albiger B, Dahlberg S, Henriques-Normark B, Normark S: Role of the innate immune system in host defence against bacterial infections: focus on the Toll-like receptors. J Intern Med 2007;261:511-528.

-31 Spirig R, Djafarzadeh S, Regueira T, Shaw SG, von Garnier C, Takala J, Jakob SM, Rieben R, Lepper PM: Effects of TLR agonists on the hypoxia-regulated transcription factor HIF-1alpha and dendritic cell maturation under normoxic conditions. PLoS One 2010;5:e0010983.

\32 Peyssonnaux C, Cejudo-Martin P, Doedens A, Zinkernagel AS, Johnson RS, Nizet V: Cutting edge: essential role of hypoxia inducible factor-1alpha in development of lipopolysaccharide-induced sepsis. J Immunol 2007;178:7516-7519.

\33 Rius J, Guma M, Schachtrup C, Akassoglou K, Zinkernagel AS, Nizet V, Johnson RS, Haddad GG, Karin M: NF-kappaB links innate immunity to the hypoxic response through transcriptional regulation of HIF1alpha. Nature 2008;453:807-811.

34 Lee KS, Scanga CA, Bachelder EM, Chen Q, Snapper CM: TLR2 synergizes with both TLR4 and TLR9 for induction of the MyD88dependent splenic cytokine and chemokine response to Streptococcus pneumoniae. Cell Immunol 2007;245:103-110. 